Tatjana Samardžija

University of Belgrade

Faculty of Philology

e-mail: tatjana.g.samardzija@gmail.com
$27-242-234=163.41=111=133.1$

https://doi.org/10.18485/ai_lik.2020.6.10.3

Оригинални научни рад

\title{
ENGLISH, FRENCH AND SERBIAN \\ TRANSLATIONS OF BIBLICAL PHRASEMESWITH \\ BETEN, MEEH AND RACHAM
}

\begin{abstract}
The paper analyses Old Testament phrasemes with the nouns beten, meeh and racham, which share the root meaning 'womb, bowels'. These phrasemes, ranging between restricted collocations and figurative idioms, belong to two semantic types: BIRTH (fruit of the womb, etc.) and HEART (one's bowels boiled/ burned/yearned, etc). We compare fifteen translations into English, French and Serbian Bible, starting from the fact that non-literal translations often delete the "image component" (Dobrovol'skij and Piraiinen 2010) responsible for the emphatic function of an idiom, thus ending in a kind of undertranslation. The relation between an idiom and its context is illustrated by a Serbian translation of Hosea 11:8.
\end{abstract}

Key words: Bible, translation, phraseme, idiom, beten, meeh, rechem, bowels, womb.

\section{Introduction}

The Old Testament (OT) Hebrew lexemes beten (נְ̣), meeh

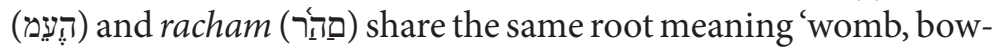
els', although their semantic fields show divergences, especially as to the range and frequencies of their respective meanings. From the phraseological point of view, beten, meeh and racham (BMR) raise interest not only because they form a number of characteristic phrasemes (e.g. in Isa. 63:15, KJV, the sounding of you bowels), but primarily because, in several of these phrasemes, BMR can alternate, as head words - sometimes two, sometimes all three, 
as in from the/my mother's womb 'since birth. ${ }^{1}$ This represents a challenge for earlier standard interpretations of idioms as more or less invariable structures.

From the cognitive point of view, BMR themselves represent dead corporeal metaphors, where body organs stand for different visceral emotions: compassion, love, pain, distress. Having thus already developped a metaphorical use each, they also form body idioms. For Warren-Rothlin:

True body idioms are expressions in which a term for a body part collocates with other words to form an expression with a new, distinct meaning. (2005:206)

Such is the case, among others, of who came forth/out of one's bowels for 'one's children', where bowels literaly means 'womb' or 'loins' (theme BIRTH), as well as of one's bowels boiled/ burned/ yearned (for someone) 'one's heart burned/yearned', implying different emotions (theme HEART). For Warren-Rothlin, corporeal metaphors establish "the relationship between 'idiomatic meaning' and 'literal meaning', together with the symbolic acts and social context which have produced the idiom" (2005:204). Idiomatic expressions based on conventional body metaphors express "by far the most common type of idioms in most languages" (2005:203), proving the importance of embodiment in personal, social and even religious experience - when Abraham sends his senior servant to find a bride for Isaac, he first swears him: "Put your hand under my thigh." (Gen. 24:2)

Since in English, French and Serbian/Croatian languages we do not find most of the phrasemes with BMR, the aim of this paper is also to discuss different choices in translation of OT body idioms with BMR into these languages. Therefore, our corpus comprises 72 occurrences of beten, 32 occurrences of meeh (or meay) and 44 occurrences of racham (plus 26 of rechem) in 6 English, 5 French and 4 Serbian/Croatian translations of the Bible, i.e. 2610 occurrences of BMR. With all the importance of dynamic translations in our search for an equivalent in the target language and target culture (Taber \& Nida 1971; de Waard 1974; Margot 1979; Loewen 1976; Warren-Rothlin 2005; van den

1 Similarly, Babut observes the alternation of plurals mothnayim and halatsim for 'loins' in gird up one's loins (1999:22; in van den Heever 2013:93). 
Heever 2013), we examine some cognitive and cultural implications of keeping the original "biblical figure" (Loewen 1976:201) in the target text, instead of its replacement by an equivalent idiomatic expression or by a non-idiomatic "plain" lexeme, both obliterating the mental image created by the original Bible figure.

We analyse Bible phrasemes and their translations from a triple theoretical platform. First of all, following Cowie's phraseological continuum (1981:225 et sqq), we place phrasemes with BMR along the continuum between restricted collocations and figurative idioms. Secondly, we consider as fundamental the notion of image component developed by the Conventional Figurative Language Theory (CFTL, Dobrovolsskij and Piraiinen 2010), and understood as a semantic interface connecting the literal and the figurative meaning of an idiom. Finally, to a lesser extent, the basic tenets of the Conceptual Integration Theory (CIT, Fauconnier and Turner 2002) have inspired us to recognize the blending of sourcelanguage and target-language idioms not only in New Testament (NT) calques of OT idioms, but also as a possible strategy in translation. We shall also take into consideration the emphatic function of idioms, which Gläser embeds in her definition of an idiom:

A «phraseological unit is a lexicalized, reproducible bilexemic or polylexemic word group in common use, which has relative syntactic and semantic stability, may be idiomatised, may carry conotations, and may have an emphatic or intensifying function in a text. (Gläser 1998:125; in Dąbrowska 2018:69; our italics)

After resuming the results of our research, opposing literal and oblique (Vinay \& Darbelnet 1972:11) translation procedures, we shall conclude the paper with a case of adoption of a Bible idiom in the DAN translation of Hosea 11:8, as a possible result of contextual contamination.

\section{Key concepts and definitions}

As mentioned, our starting point in this paper is Cowie's phraseological continuum free combinations $\rightarrow$ restricted 
collocations $\rightarrow$ figurative idioms $\rightarrow$ pure idioms (1981:225 et sqq), primarily because of its scalarity, encompassing all semantic variations of phrasemes. For Cowie, pure idioms (e.g. curry favour, foot the bill, 1981:228) are "as immutable as they are semantically opaque", while figurative idioms like do a U-turn or change gear "have figurative meanings", but "also preserve a current literal interpretation" (1981:229). As for free combinations with BMR (e.g. barren womb in Pro. 30:16 for racham; fish's belly in Jon. 1:17 for meeh; Judges 3:22 for beten), they are not the subject of our present interest. Most of the occurrences of BMR are in phrasemes spanning between restricted collocations and figurative idioms, such as, for example, from the womb 'from birth' (beten, meeh, racham), who opens the womb 'firstborn' (racham), or the sounding of one's bowels 'compassion, tenderness' (meeh, Isa. 63:15).

The second theoretical frame we use is the CFTL, whose authors argue that a typical idiom

can be interpreted on two different conceptual levels: on a primary level, i.e. on the level of its 'literal' meaning which underlies its inner form, and on a second level, i.e. on the level of its figurative meaning. [...] The so-called image component of an idiom takes the role of a semantic bridge between the two levels. What is meant by image component is neither the etymology nor the original image, but linguistically relevant traces of an image that are comprehensible for the majority of speakers. It is an additional conceptual link that mediates between the literal reading (fixed in the idiom's lexical structure) and the lexicalized meaning of an idiom [...] (2010:74,75; original italics)

This obviously describes Cowie's figurative idioms (Cowie, 1981:229), while pure idioms no longer offer direct insight into their motivation, and must be interpreted globally. To explain the concept of image component, Colson mentions the analysis of caught between a rock and a hard place, which cannot be used for all difficult situations, because the literal meaning of the idiom 
creates "the mental picture of being between the two obstacles, i.e. the idea of a lack of freedom of movement" (Dobrovolsskij and Piraiinen 2005:15, in Colson 2008:196; our italics). For example - contrary to the motherly love of 1 Kings 3:26 (her bowels yearned upon her son, KJV), where the literal and the figurative meaning are merged since refering to a woman who has just had a baby - the deep Joseph's love for his brother in Gen. 43:30 (his bowels did yearn upon his brother, KJV) no longer designs that physiological and psychological bond between a mother and the fruit of her womb, but the bond of two brothers born of the same mother. The image component common to both occurrences of the idiom still tells us that "blood is thicker than water". It represents love as a deeply embodied emotion linked with our origins. In fact, the root meaning of the plural rachamim inevitably affects the perception of the idiom as a whole. In Bible idioms, it is essential to remember that "the image component is influenced by the culture of the specific language, and can therefore yield a lot of information about differences in culture, especially when very remote languages are the object of investigation" (Colson, 2008:196). The concept of motivation discussed by Dobrovol'skij and Piraiinen (2010) is defined by Langlotz as "a speaker's ability to make sense of an idiomatic expression by reactivating or remotivating their figurativity, i.e. to understand why the idiom has the idiomatic meaning it has with a view to its literal meaning" (Langlotz 2006:45, in van den Heever 71).

Motivation, as a bridge connecting these two levels of meaning, seems to be the major point of difference between Cowie's figurative and pure idioms : the motivation of figurative idioms is more or less accessible, while it is lost in pure idioms like kick the bucket (Mark 2:19, KJV, 'bridegroom's guests at a wedding).

On the other hand, Warren-Rothlin (2005:201 et sqq.) seems to suggest that the loss of motivation can be explained by the fact that "culture-specific symbolic acts" which had produced such idioms have since been lost to the community so that the connection between literal and figurative can no longer be retrieved. Such is the symbolic act of taking one's hat off to someone, which is verbalized as an expressive speech act in English, French and 
Serbian. Warren-Rothlin uses this example to distinguish four stages of idiomatization of social experience: 1 . the action itself first becomes symbolic (wearing a hat representing social superiority, so that to lift or to take it off expresses high regard for someone); 2. The symbolic act is metaphorized to mean 'congratulation'; 3. The metaphor loses its literal reference and is idiomatized; 4. The meaning of the symbolic act is expressed by the corresponding speech act, even in the absence of the former. To resume, idiomatic expressions are linguistic traces of psychological and sociocultural components, whether the latter still be active or not. For us, this clearly implies that to translate such an idiom by a plain expression would erase an important segment of meaning clearly intended by the original text.

Moreover, for Langlotz, "the internal semantic structure of idioms is potentially variable from speaker to speaker: while an idiom may be motivated for speaker $\mathrm{A}$, it is potentially opaque for another speaker B" (2006:127; in van den Heever 2013:71; our italics) because of our "mental network that can be potentially activated". Quite similarly, Fernando, who also shares a scalar approach to idiom classification, argues that the readers'/ listeners' knowledge of the grammar and of the context of use (1996:240, in van den Heever 2013:53) influences directly their capacity to recognize the figurative level of meaning. Therefore a translator of the Bible must always be aware of the public targeted by the translation and their capacity to recognize and appreciate the correspondence of the literal and the figurative meaning in the translation of idiomatic expressions. ${ }^{2}$

Thirdly, the Conceptual Integration Theory aims at explaining how we "make connections between different stories" (Turner, 2007:377-378), i.e. how initially distinct mental spaces (but containing common semantic elements making analogy possible) behind two or more expressions blend into a new and complex one, which inherits both the shared and some individual features mapped from the two input spaces onto the blended one. Thus, in Chrystal's

2 The crucial questions raised by E. Cary are: What do you translate? When, where, for whom? (Fr. orig. "Que traduisez-vous? Quand, où, pour qui?"; 1985:35) 
example with a monkey in a zoo reading Darwin and saying Am I my keeper's brother?, ${ }^{3}$ the new expression merges the properties of the input space of the Bible idiom Am I my brother's keeper? (Cain as a bad "keeper" of Abel) with those of the other input space (Darwin: apes and men are relatives) into the blended space (apes are mistreated relatives of men), on the basis of their shared features contained in the generic space (kinship). As for the Bible, Colossians 3:12 blends two OT body metaphors: BOWELS ARE (A SEAT OF) EMOTIONS (e.g. Song 5:4), and CLOTHES ARE CHARACTER (e.g. Isaiah 61:10) into the complex idiom put on the bowels of mercies, meaning simply 'be merciful.' ${ }^{4}$ Conceptual integration could be of a particular interest when a translator wants to avoid both literal translation, for its incomprehensibility, and equivalence/ plain lexeme, for its loss of the image component. In this case, we argue, the translator could opt for a blended translation, combining (elements of the) original idiom with: a) a target language idiom of a different literal meaning or b) a target language plain word. For example, while splancha in Phi. 1:7,12,20 is rendered literally in the KJV, the DRB and the DBY, and replaced by heart in the NIV, the NASB and the NKJV, we find a blended translation in the KJV for 1 John $3: 17$, where literal translation of bowels is enriched by adding the plain compassion (bowels of compassion), so that the image component is saved, as well as the clarity of meaning.

Finally, we underline as essential the emphatic or intensifying function of idioms. This function has a discursive and psychological motivation: the use of idioms often aims at a picturesque expression of intense emotional or sensory states. Nunberg, Sag and Wasow

3 The Influence of the King James Bible on the English Language. Conference organised by the English Speaking Union, British Council, July 62011 , on the occasion of the $400^{\text {th }}$ anniversary of the KJV Bible (2011:40:50).

4 Moreover, bowels of mercies (splanchna oiktirmou) seems to be a contraction of the OT parallelism bowels and mercies (e.g. Isa. 63:15; see also Hos. 2:19, Zec. 7:9) as a kind of explicitation of bowels. This Paulian formulation reminds us of Langlotz' "hybrid images" (2006:125; in van den Heever 2013:73). For Langlotz, conceptual blending is one of "conceptual mechanisms" on which idioms are based, others being conceptual metaphor, metonymy and emblems (in wolf in sheep clothing, wolf is an emblem of evil; 2006:124). Warren-Rothlin takes synecdoche as a subtype of metonymy (2005:100). 
(1994:492-493; in van den Heever 2013:42) discern six "dimensions of idiomaticity" ascribed more or less to various phrasemes: conventionality ${ }^{5}$ (stereotyped use in a linguistic community), inflexibility (reduced syntactic variability), figuration (frequent presence of a metaphor, metonymy or hyperbole in the phraseme, opposing the literal and the figurative meanings), proverbiality (phrasemes reflect various facets of social experience), informality (association with colloquial and familiar styles) and affect (affective stance in the speakers attitude, instead of neutrality). The emphatic function concerns both informality and affect. This is obvious from the notable absence of idioms in administrative and professional contexts. In the Bible, idioms are closely connected with their cultural context and the attitude of the enunciative stance (speaker) towards the discursive context and content. Furthermore, the emphatic function of idioms depends on the simultaneous perception of the literal and the figurative meaning: yearning bowels does not bear the same connotational value as plain lexemes compassion or pity - precisely because of the absence of image component in the latter. Compared to their plain equivalents (kick the bucket - die), idioms contain a surplus of (con)textual meaning, which often reveals the presence of a particular enunciative stance (Fr. instance énonciative. In this sense, it is interesting to note the high frequence of idioms with BMR in Job, Psalms and Isaiah. As Taber and Nida mention five factors to be considered when translating a "biblical expression", the last but not the least is the "emotional reaction of the targeted public". (Taber et Nida, 1971:107; in Margot 1979: 93; our translation)

\section{Interpretation and translation of idioms}

Loewen mentions four main types of "adjustments in translation" 6 in his third article on "Non-literal meanings" (1976:201):

$5 \quad$ Vrbinc reminds us with Dobrovol'skij that, "as soon as an expression has become conventionalized, it will be reproduced in discourse as prefabricated unit of language" (Dobrovol'skij 2006:514; in Vrbinc 2019:12). In the context of Bible translation, we find the term memorisation (Maria Swensson 2004:184, in van den Heever 2013:65).

6 These four types are practically identical with those proposed by de Waard (1974:114-115). 
1. Keeping the original biblical "figure" in the target text (calque, refresh my bowels in the Lord, KJV); ${ }^{7}$

2. Adding elements which are implicit in the biblical idiom (i.e. explicitation, ${ }^{8}$ Aie, mon ventre, mon ventre me fait mal!, Jer. 4:19, NFC, vs. the original My bowels! My bowels!, YLT);

3. Replacing the original idiomatic expression by a "culturally equivalent" (Margot, 1979:93), i.e. a target language expression of similar meaning (e.g. in Song 5:4 the Serbian-Croatian srce mi ustrepta 'my heart trembled', ZBS, vs. the literal my bowels were moved, KJV);

4. Expressing the figurative meaning "in plain words", i.e. in a non-figurative way (his children instead of those that came forth of his bowels).

When choosing among these four, a translator ought to respect the three Taber and Nida's $(1982: 118,119)$ priorities "in the proces of transfer":

"1. At all costs, the content of the message must be transferred with as little loss or distortion as possible. It is the referential, conceptual burden of the message that has has the highest priority.

2. It is very important to convey as well as possible the connotation, the emotional flavor and impact, of the message.

3. If, in transfering from one language to another the content and the connotation of the message, one can also carry over something of the form, one should do so. But under no circumstances should the form be given over the priority over the other aspects of the message." (Taber and Nida, 1982:118,119; our italics)

If the third "priority" clearly warns against the "errors of literalism" (Margot 1979:94), all three priorities warn against the loss of message, including its "emotional flavor and impact". As M. Bouttier puts it, "biblical words are heavy with different evocations and resonances". ${ }^{9}$ While non-literal translation techniques

7 Our examples. Similarly, de Waard's first principle of translation affirms that, "in spite of the temporal and cultural distances, the Biblical form should be respected and retained with or without modification whenever possible." (1974:113-114)

8 Or amplification in Vinay and Darbelnet (1972:5).

9 "Les mots bibliques sont lourds d'évocations et de résonances" (M. Bouttier, 1972/3:373, in: Margot 1979:24). 
can surely enhance the reader's understanding of the basic-level message of the Bible, they will certainly result in the loss of the emphatic function of the source idiomatic expression, which also contributes to this basic message.

From the cognitive point of view, figurative idioms like those containing $B M R$, where literal and figurative are superposed, reveal a particular cultural perception of body-mind correlations. Therefore, the translation of a Bible idiomatic expression with a plain non-idiomatic denotative equivalent or with a target-culture idiomatic expression of a similar figurative, but different primary meaning, results in the loss of "etymological memory" and reduces the image component which links the literal and the lexicalised levels of meaning (Dobrovol>skij and Piraiinen 2010:85 et sqq). This is why Margot, commenting on a non-figurative translation of Pro. 5:15-18, remarks that it "has not preserved any image" (1979:291). He remains opposed to consistent demetaphorization "without compensation" (1979:290.

Commenting on a Schleichermacher's 181? lecture entitled "Über die verschiedenen Methoden des Übersetzens" ("On the Different Methods of Translating"), L. Venuti opposes two fundamental translation strategies: contrary to what he calls the domesticating strategy ("an ethnocentric reduction of the foreign text to target-language cultural values"), ${ }^{10}$ he underlines the importance of the foreignizing strategy which is "an ethnodeviant pressure on [target-language cultural] values to register the linguistic and cultural differences of the foreign text, sending the reader abroad" (Venuti 2001:242; our italics). This dichotomy is particularly relevant for Bible translations: with the exception of those cases where a calque would result in misinterpretation, ${ }^{11}$ the fear

10 Margot (1979:91,92) quotes some eloquent examples of far-fetched "equivalences" in R. Parmentier's translation of Matthew, such as comrades (Fr. camarades) for disciples; enigmas (énigmes) for parables; the grand project (le grand projet) for The Kingdom of God. Even more exaggerated are examples we find in Clarence Jordan's Cotton Patch paraphrase of the New Testament, written in the 1960s and 1970s for the US South, where Jew and Gentile are replaced by white man and Negro, and cricifixion becomes lynching.

11 E.g. children of the bridechamber in the KJV Mat. 9:15, means 'the guests of the bridegroom', Ser. svatovi, Fr. les amis de lépoux, and not 'children 
of losing the reader to the effort of surpassing his or her own worldview has oftetimes deprived many a translation of that distinctive civilisational dimension of the Bible text. But the problem concerns one more dimension.

Referential and even hermeneutical loss produced by the deletion of an apparently insignificant and banal Hebraism can be seen if we compare an English and a Serbian translation of

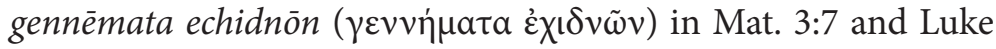
3:7. While the VUK (1847) translates the phrase literally as porodi aspidini!, lit. 'brood/children of viper', like most renowned English translations (including NIV, NASB and NKJV), the Good News Bible (GNT, previously called Todayıs English Version) has You snakes! ${ }^{12}$ Such an equivalence results from the choice to shorten the koine Semitism son of + noun (Man, perdition, Israel, prophets, thunder... $)^{13}$ to noun only. Similarly, it is highly probable that an average Serbian reader will interpret porodi aspidini as equivalent to You snakes (Ser. Zmije!), regardless of its literal translation. In that case, can we say that the strategy of the GNT was correct? The problem is that John the Baptist did not intend an insult. He meant it literally. Namely, besides the Baptist, Christ himself uses the same formula twice, in Matthew 12:34 and 23:33. It is Christ also who in John 8:44 shows clearly that he means what he says: „Ye are of a father - the devil..." (YLT). For him, $\gamma \varepsilon v v \eta \dot{\mu} \mu \alpha \tau a$ $\dot{\varepsilon} \chi\llcorner\delta \nu \tilde{\omega} v$ points at the spiritual descendance of the devil (or the Serpent, cf. Rev. 12:9). In all these NT texts, viperss brood is a reference to Gen. 3:15: "And I will put enmity between thee and the woman, and between thy seed and her seed; it shall bruise thy head, and thou shalt bruise his heel." Therefore, to translate/

conceived in the bridechamber'. See on this example de Waard 1974:112. Dagut speaks about hypnotization by metaphors: when translators learn the etymology of a dead metaphor, they are so impressed that "they cannnot free themselves from its domination". (Dagut 1971:117; in de Waard 1974:113)

12 Margot (1979:287) quotes this translation from GNT as one of examples taken from Loewen (TBT 27.2, 1976:207-209). Still, Margot mentions it in a different context.

13 For Margot (1979:277-278; our translation), this phrase designates "posession of a quality, or belonging to a group, or someone's doom". It can be understood "as positive or negative, or taken as neutral". 
interpret Porodi aspidini as a mere critique of someoness character darkens the important interpretive reference to the key text in Genesis. Bible translations must harmonize transculturation with hermeneutics.

For de Waard, following Katharina Reiss (1971:62f, in de Waard 1974:112), an important criterion in translation is the type of discourse: in non-literary prose, the accent is on the content, justifying plain translation; in a poetic text, demetaphorization "necessarily implies a considerable loss of impact of the message" (de Waard 1974:112), because it replaces the often powerful imagery by a "flat and uninteresting translation which would have to be judged as an 'under-translation"' (ibid).

Therefore, whenever is possible to find an equivalent which shares some generic space components with the source expression, without the risk of absence of motivation from the perspective of the target culture or even of misinterpretation, the translation should at least be a blend of the source and the target input spaces, preserving the image component characterizing the Bible idiom, and expanding it by adding components from the target culture. This seems to have been not only Paul's strategy in Col. 3:12, but also that of Peter in 1 Pet. 1:13, since gird up the loins of your mind activates the OT gird up one's loins and explicitely applies it to the spiritual domain (your mind) for the non-Hebrew public (explicitation in terms of Vinay and Darbelnet 1972:9).

\section{Womb and bowels in biblical idioms}

Our research concerns phrasemes with three Hebrew

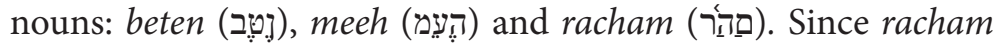
has a doublet, rechem, with the same root meaning 'womb', we also take into consideration its 26 occurrences. For each of the three lexemes, we will study its meaning and its translations into English, French and Serbian. After that, we will resume our observations.

The corpus comprises:

- 72 occurrences of beten,

- 32 occurrences of meeh (or meay) and 
- 44 occurrences of racham (and 26 of rechem)

for each of the 15 following translations:

- In English: DRB (the Douay-Reims Bible, 1582-1610), KJV (the King James Version, 1611), DBY (the Darby Translation, 1890), NASB (the New American Standard Bible, 1971), NIV (the New International Version, 1978), NKJV (the New KJV, 1982);

- In French: OST (the Ostervald Version, 1724), LSG (the Louis Segond Version, 1910), TOB (the Traduction Oecuménique de la Bible, Ecumenical Translation of the Bible, 1967-1975), CHU (the André Chouraqui Version, 1974-1979), NFC (the Nouvelle Français Courant, 2019);

- In Croatian/Serbian: DAN (the Đuro Daničić Old Testament, 1865), BAK (the Lujo Bakotić Version, 1933), ZBS (Zagrebačka Biblija "Stvarnost", 1968), SSP (the Savremeni Srpski Prevod, 2016).

By contrasting translations in each of the three languages, we will identify several translation procedures or techniques from the list of Vinay and Darbelnet (1972:4-16), with a special focus on the emphatic dimension of the phrasemes with BMR. Concerning translations, we have noticed expected tendencies, but not always regularities, as individual versions mostly do not render each lexeme or phraseme in the same way. A notable exception is the Chouraqui translation (CHU), where every beten is ventre, every rachamim is matrices, while meeh can be replaced by the plurals boyaux, entrailles or viscères. With a limited frame of this paper, we shall accentuate only verses of a particular interest.

The following table shows the semantic distribution of the four lexemes: 


\begin{tabular}{|c|c|c|c|c|}
\hline Main meanings & $\begin{array}{c}\text { beten (נְטֶ) } \\
72\end{array}$ & $\begin{array}{c}\text { meeh (הָעִמים) } \\
32\end{array}$ & $\begin{array}{c}\text { racham (פחר) } \\
44\end{array}$ & $\begin{array}{c}\text { rechem } \\
26\end{array}$ \\
\hline womb & 44 & 4 & 4 & 26 \\
\hline $\begin{array}{l}\text { man's centre of } \\
\text { procreation }\end{array}$ & 1 & 5 & & \\
\hline $\begin{array}{l}\text { internal organs, } \\
\text { intestines }\end{array}$ & 14 & 11 & & \\
\hline external belly & 1 & 1 & & \\
\hline $\begin{array}{l}\text { body (opposed } \\
\text { to soul) }\end{array}$ & 2 & & & \\
\hline 'heart', emotions & 9 & 11 & $\begin{array}{c}\text { compassion } \\
39\end{array}$ & \\
\hline woman & & & 1 & \\
\hline $\begin{array}{l}\text { piece of } \\
\text { architecture }\end{array}$ & 1 & & & \\
\hline
\end{tabular}

The table shows that beten develops a greater variety of meanings than other lexemes (although 'womb' is dominant), compared to racham, which is used predominantly in its figurative meaning of 'compassion', while its doublet rechem is used exclusively for 'womb', without figurative use.

From a strictly semantic point of view, we can distinguish two main semantic types of phrasemes: the type BIRTH and the type HEART. All three lexemes form both types of phrasemes.

The type BIRTH is based on the metonymy womb-birthchild. While racham forms both types of lexemes, the majority of its occurrences are in plural (rachamim), in which case they have a metaphoric meaning 'compassion' (type HEART), as of a motherly compassion for her child, so that the rare singular occurrences of racham correspond to the type BIRTH (Gen. 49:25; Eze. 20:26), as well as all the occurrences of its morpho-semantic doublet rechem (e.g. Gen. 20:18; Hos. 9:14). Here are the phrasemes of the type BIRTH in the KJV:

$\mathrm{B}$ : fruit of the womb, from the/my mother's womb/belly, children of my own body, son of one's womb

M: out of one's bowels, come forth of one's (own) bowels, from the bowels of one's mother (= from the womb) 


\section{$\mathrm{R}$ : from the womb, all that opens the womb}

In come forth/proceed from one's bowels (B, M), 'originate from, be a child of', the literal sense of bowels is obvious, just as of womb (B) in fruit of the womb and the offspring of one's bowels ('children, descendants'), which are highly restricted collocations, i.e. combined with a restricted list of nouns and producing a rather transparent meaning. Still, fruit for the child is already an emphatic way of expressing parenthood, such as highlights the deep attachment of one's inner being to his/her children. In all three cases, the stress is on the image component of delivery/birth in order to emphasize the powerful parental connection. The same image of delivery/ birth is evoked in all that opens the womb (racham, rechem) for 'fistborns'. The phraseme from the/one's womb/bowels meaning 'since one's birth, since one was born' differs from others in this group, and in the other, by being the only phraseme in which all the three lexemes can alternate (e.g. B-Job 10:19, M-Isa. 49:1, R-Isa. 46:3). This phraseme is based on the metonymy taking womb for birth, and is used as temporal adverbial. It is a relatively fixed expression, but without any figurative meaning.

The type HEART includes phrasemes whose figurative meaning is based on the corporeal metaphor representing bowels and the womb (conceptualised as situated in the bowels) as the seat of powerful emotions which range from parental love and yearning to desire as well as pain. In fact, as we shall see, BMR forms parallels with nefesh 'soul' and leeb 'heart', also refering to character in general. Here are the phrasemes of the type HEART in the KJV:

B: my belly trembled, the inner/inmost parts of the bowels (the inner being)

M: my bowels were moved/stirred/troubled ('I was moved, in distress'), one's bowels shall sound (+ compl.) or the sounding of one's bowels

$\mathrm{R}$ : one's bowels yearn for someone (son, brother), the sounding of thy bowels $(M)$ and of thy mercies (R), His (God's) mercies are (very) great/ great are thy (God's) mercies, thy manifold mercies, God's tender mercies

While the type BIRTH is based on metonymy, this type is based on a conceptual metaphor, as another one of Langlotz' 
"conceptual mechanisms" producing idioms (2006:124; in van den Heever). Here organs such as womb and bowels (belly) are conceived as seats of deep emotions (Isa. 49:15, B). The comparison of the two types of phrasemes shows that they are connected and represent a continuum where the literal meaning is potentially retrievable in the figurative use. In fact, in figurative idioms of the type HEART, we find the superposition of the literal and the figurative meaning: while in English, French and Serbian, such correlation exists between heart and emotions, in Hebrew, the seat of emotions is not only heart, but also womb and bowels, as well as kidneys and liver. On the other hand, this type comprises also restricted collocations such as His (God's) mercies are (very) great/ great are thy (God's) mercies, in thy manifold mercies, God's tender mercies. Of course, as for mercies, rachamim is itself a metaphor. Actually, Warren-Rothlin recognizes "multiple metaphorizations" involving not only the whole phraseme, but also some of its parts (2005:101); he mentions nouns, as is the case with BMR. As we shall see, while earlier of our 15 translations tend to render such idioms by a more or less faithful calque, the recent ones often replace them by their equivalents with heart or with dynamic equivalents. Our analysis will show that these versions do not systematically translate all occurrences of the type HEART in the same way: some occurrences are translated literally in all versions, while others are rendered in a different manner from version to version, and even in one version. For a deeper look at the translations of the phrasemes with BMR, we shall consider each of lexeme apart.

\subsection{Beten: meaning, parallelisms and translations}

\subsubsection{Meanings and parallelisms of beten}

Brown, Driver and Briggs ${ }^{14}$ distinguish four main meanings of beten (feminine, singular, 72 occurrences):

$14<$ https://biblehub.com/hebrew/990.htm> 21.04.2019. 
1) human belly, abdomen (Job 20:15,20,23; Psa. 17:14); belly of the behemoth;

2) body "opposed to soul" (Ps. 31:9; Ps. 44:25); ${ }^{15}$

3) womb (Gen. 25:23,24; Hos. 12:4; Job 1:21; Eccl. 11:5; Isa. 44:2,24 etc.), and figuratively (Jon. 2:3: the womb - i.e. the hole of the Sheol; Job 38:39: Out of whose womb came the ice?) and

4) inner being (Job 15:35; 32:18, etc.).

While beten primarily refers to the womb, ${ }^{16}$ it can also imply the reproductive parts of a man (Job 19:17; Mic. 6:7). Exceptionally, in 1 Kings 7:20, beten is said to represent a terminological metaphor for "some rounded projection connected with the two pillars Jachin \& Boaz" (Brown-Driver-Briggs). ${ }^{17}$

Beten forms 17 parallelisms:

1) beten+meeh ('womb'): in thy womb... from thy bowels (Gen. 25:23); from the womb... out of my mother's bowels (Psa. 71:6); from the womb... from the bowels of my mother (Isa. 49:1); thy belly... thy bowels (Eze. 3:3);

2) yarek ('thigh')+beten: thy thigh to rot... thy belly to swell (Num. 5:21); beten+yarek: thy belly to swell... thy thigh to rot (Num. 5:22.27);

3) beten+rechem ('womb'): in the womb... in the womb (Job $31: 15$ ); in the belly... from the womb; (Jer. 1:5); rechem+beten: from the womb... as soon as they be born (Psa. 58:3);

4) mothen+bethen (centre of strength): in his loins... in the navel of his belly (Job 40:16);

5) racham+beten ('womb'): from the womb... from my mother's belly (Psa. 22:10); beten+racham: from the belly... from the womb (Isa. 46:3);

6) nephesh+beten ('soul and body'): our soul... our belly (Psa. 44:25); his soul... the stomach (Pro. 13:25);

$15 \quad$ Are Psa. 31:9 and 44:25 really syntetic, or rather antithetic parallelisms? Are beten and nefesh forming a merism, as Brown, Driver and Briggs seem to suggest, thus linking two opposites (body, soul) to represent the whole (all human being), or, as we are inclined to think, is beten represented as the seat of nefesh?

16 \#Strong's Exhaustive Concordance derives beten "[f]rom an unused root probably meaning to be hollow [...]”. <https://biblehub.com/hebrew/990. htm $>$ 12.3.2020.

ibid. 
7) banim+pDri habaten: children... the fruit of the womb (Psa. 127:3);

8) firstborn-fruit of my beten: my firstborn... the fruit of my body (Mic. 6:7).

Sometimes the KJV designates by belly the centre of human soul (since beten forms parallelisms with nefesh in Psa. 44:25 ans Pro. 13:25), like in Job 32:19; Psa. 31:9; Psa. 44:25; Pro. 18:8 (identical with 26:22); Pro. 20:27.30; Pro. 21:18. Beten is clearly represented as the centre of emotions in Hab. 3:16.

Exceptionally, in Job 19:17, the literal meaning of libne bitni ("to the sons of my womb/body") assigns beten to Job, which is close to the use of halats-mothen (loins). Still, there is considerable discrepancy between the translations of this particular verse: compared to Young's litteral the sons of my mother's womb, we read the children's sake of mine own body (KJV, see also Mic. 6:7), the children of my womb (DRB), the children od my [mother's] womb (DBY), my own family (KJV), my own brothers (NASB) and the children of my own body (NKJV).

\subsubsection{Contrastive analysis of English, French and Serbian translations of beten}

Gen. 30:2 is the first text with the fruit of the womb, but in a complex context. All English versions keep womb, except the NIV, with its equivalent who has kept you from having children. French translations tend to equivalence: qui t'empêche dêtre féconde (LSG); qui t'a refusé la fécondité (OST); qui n’a pas permis à ton sein de porter son fruit (TOB); C'est lui qui t'empêche d'en avoir (NFC). Expectedly, the CHU keeps the calque. The Serbian BAK uses three times the plural utrobe (Isa. 13:17; Mic. 6:7; Hab. $3: 16$ ) for both types of phrasemes, although beten is singular.

In Deu. 7:13, the fruit of thy/your womb is in all English versions. All French versions keep fruit, whether of tes entrailles, ton ventre, ton sein or ton corps. In Serbian, the ZBS, the DAN and the BAK keep plod utrobe, but the recent SSP has the plain tvoj porod.

As for the five verses in Deu. 28 and 30, where the KJV has fruit of thy body (synecdoche: part-whole), and the rival DRB, fruit of thy womb, the DBY oscillates with the fruit of thy womb/ 
body. The NIV and the NKJV only modernize the pronoun into your. The NASB goes further, combining offspring with body. In French, the LSG and the OST have le fruit de tes entrailles, the $\mathrm{TOB}$, le fruit de ton sein, and the CHU, le fruit de ton ventre. The NFC has various solutions: once le fruit de ton corps, besides three de nombreux enfants, ta descendance and ton fils et ta fille.

The three following occurrences of from the/my mother's womb relate to Samson. Here all English versions have womb. The French versions are internally coherent, with, respectively, dès/ depuis le ventre de sa/ma mère (LSG, CHU, NFC) and dès/depuis le sein (OST, TOB). All Serbian/Croatian translations keep the idiom with utroba.

The 16 occurrences in Job deserve a particular attention: here beten forms not only phrasemes we study, but also several literary metaphors we will mention. As for the phrasemes of birth, Job 1:21; 3:10.11; 10:19 show great faithfulness of the English versions to the original, with womb and belly everywhere. We mention in particular from womb to tomb in the NASB, excellent equivalent idiom, and from the womb to the grave elsewhere. For the sake of comparison, Serbian/Croatian has a very similar idiom od kol(ij)evke pa do groba (lit. 'from the cradle to the grave'), but none of the 4 respective Serbo-Croatian translators used it. In French, we mention the non-literal translation Car elle n'a rien fait pour mempêcher de naître (NFC, 3:10). In 10:19, verbs porter, passer, transporter seem to prevent idiomatic reading (Fr. défigement). As for the non-conventional metaphoric use of beten in Job, let us first mention 15:2 (fill his belly with the east wind, KJV), where translations rightly keep the image, but vary the lexeme for the wind: east wind, sirocco, etc. Also, the LSG and the OST translate beten with poitrine, breast, chest'. In $15: 35$, their belly prepareth deceit (KJV) suggests the metaphorical use of beten for the mind, which is why the NASB has mind, and the NFC uses synecdoche with ce qui mûrit en lui, c'est la tromperie. All Serbian versions keep the metaphor. As in Job 15:2 and 15:35, the link between beten and our literal and spiritual appetite and emotions is visible also in Job 20:15.20.23 (see Psa. 17:14; 31:4; Pro. 18:20; 20:27,30; 22:18; Pro. 26:22). Job 32:19 underlines the metaphorical use of beten to express intense emotions. We 
find special interest in Job 38:18, where bitni literally refers to 'my bowels/womb', but is always translated with a synecdoche, e.g. the spirit within me (NIV). In French, 38:18 is rendered literally by the OST (l'esprit qui est dans mon sein), the TOB and the CHU (le souffle de mon ventre), while the NFC uses the transposition ${ }^{18}$ mon agitation intérieure. All Serbian versions use synecdoche. Job 38:29 uses a beautiful literary metaphor, From whose womb has come the ice? (NASB), which all versions render faithfully.

Psa 58:3 illustrates the usual translation of parallelisms with from the womb (see also Psa. 71:6) and fruit of the womb. While the older translations keep the image both of rachem ('womb') and of beten ('belly, womb'), such as DRB, many more, in parallelisms in general, render one of the two lexemes with a plain word. Such is the case here with all other but the NFC, which replaced both beten and rechem with a plain word. In Psa. 127:3 and 132:11 fruit of the womb/body is kept in most English versions, apart from the NIV (offspring, descendants), while the French TOB and NFC condense only Psa. 132:11; so do the ZBS and the SSP.

As for the Proverbs, we mention the more or less successful versions of 31:2, where the mother speaks to the son of my womb (KJV): while all English and most French versions keep the phraseme, the NFC has mon propre enfant to express emotional attachment, but losing the image. In Serbian, while the DAN and, surprisingly, the SSP keep the phraseme (sine utrobe moje), the ZBS replaces utroba with srce, thus using the equivalent organ. The BAK solution is the most beautiful, but the image is lost as well, with moj rodeni.

Ecc. 5:15 is, with Job 1:21, the example of a $100 \%$ faithful translation in all 15 versions, because of the famous 'coming forth naked from one's mother's womb'.

The most powerful uses of beten are found in the Prophets. Isaiah has 8 occurrences. The image with the womb is rather consistently kept in the KJV, the DRB and the NKJV. As for the others, once more, the parallelism in Isa. 46:3 and 49:1 leads to the replacement of one of the lexemes by a plain word (birth, borne in the NIV and the NASB in particular). In the famous Isa. 49:15,

18 According to Vinay and Darbelnet, transposition is a change of word class, like here merciful replaces mercy. (Vinay \& Darbelnet 1972:16) 
the absence of parallelism leads to a generally literal translation fruit of her womb in all English versions but the NIV (the child she has borne), all French but the NFC (l'enfant qu'elle a porté) and all Serbian/Croatian but the SSP (dete koje je rodila). We argue that the possible reason for this faithfulness resides in Luke 1:42, where the same phrase is used for Jesus Christ: blessed (is) the fruit of thy womb in the KJV, blagosloven je plod utrobe tvoje in the DAN, le fruit de ton sein est béni in the LSG.

As for the parallelism in Jer. 1:5 (beten+rechem), there is significant inconsistancy in English versions, with only the KJV and the DBY keeping both phrasemes (belly, womb). French versions keep both phrasemes. Of the Serbian/Croatian versions, the SSP has replaced the phraseme with meeh using the equivalent pre nego što si se rodio.

The occurrences in Hosea, Micah, Jonah and Habakkuk are placed in the context of powerful emotional messages. Nonetheless, we mention only Hab. 3:16, as it contains the only conventional phraseme of the type HEART. In English versions, we have my body/belly/bowels trembled/were troubled, except in the NASB, with the awkward my inward parts trembled. In French, the TOB and the NFC read je suis profondément bouleversé, while the CHU has the doubtful mon ventre s'irrite. Serbian/Croatian versions all have the calque (pl. utrobe in the BAK).

In Serbian/Croatian versions, the lexeme utroba 'bowels' is predominant in the $\mathrm{ZBS}$, the DAN and the BAK, whereas the SSP (2016) uses concentration (Vinay and Darbelnet 1972:7) to replace 'the fruit of the womb' by potomak, porod 'descendant, offspring', odojčad 'sucklings' and deca 'children'. The BAK and the SSP often replace od utrobe materine 'from one's mother's womb' with od rodenja 'since birth'.

\subsection{Meeh: meaning, parallelisms and translations}

\subsubsection{Meaning and parallelisms of meeh}

In meeh (32 occurrences, masculine, always plural!), there is an uninterrupted semantic continuum, from its literal meaning 
'belly', 'intestines', 'womb', to 'birth', to '(motherly) compassion'. We can identify 4 main meanings, 3 of which (21 of 32 occurrences) are literal:

1) Bowels or abdomen: 2 Sam. 20:10; 2 Chr. 21:15 (disease of thy bowels),18,19; Job 20:14 (his meat in his bowels); Song 5:14 (external belly); Eze. 3:3 (fill thy bowels with this roll); Jon. 1:17 (fish's belly); 2:1 (or 2:1.2);

2) Woman's centre od procreation, womb (see beten, rechem and racham): Gen. 25:23; Num. 5:22; Ruth 1:11 (are there yet any more sons in my womb); Psa. 71:6 (took me out of my mother's bowels); Isa. 49:1;2;

3) Man's centre of procreation (similar to halats): Gen. 15:4 (out of thine own bowels shall be thine heir); 2 Sam. 7:12, 16:11; 2 Chr. 32:21 (they that came forth of his own bowels slew him); Isa. 48:19;

4) Center of powerful, deep (visceral) emotions and sensations (see racham): Job 30:27 (my bowels boiled); Psa. 22:14 (my heart is melted in my bowels); Psa. 40:8 (thy law is in my bowels); Song 5:4 (my bowels were moved for him); Isa. 16:11 (my bowels shall sound like an harp for Moab); Jer. 4:19 (My bowels! My bowels!); Lam. 2:11 (my bowels are troubled).

The full span of meanings of meeh appears in 12 parallelisms and appositions:

1) meeh+beten ('womb'): Gen. 25:23 (Two nations are in thy womb, and two manner of people shall be separated from thy bowels); Psa. 71:6 (By thee have I been holden up from the womb: thou art he that took me out of my mother's bowels); Isa. 49:1; Eze. 3:3;

2) meeh+beten+yarek ('bowels'): Num. 5:22 (And this water that causeth the curse shall go into thy bowels, to make thy belly to swell, and thy thigh to rot);

3) meeh+kereb (emotions, 'soul') : Isa. 16:11 (Wherefore my bowels shall sound like an harp for Moab, and mine inward parts for Kirharesh);

4) zera+meeh ('fruit of the womb'): Isa. 48:19 (Thy seed also had been as the sand, and the offspring of thy bowels like the gravel thereof ); 2 Sam. 16:11;

5) meeh+racham ('compassion"): Isa. $63: 15$ (therefore my bowels are troubled for him; I will surely have mercy upon him); 
Jer. 31:20 (where is ... the sounding of thy bowels and of thy mercies toward me?);

6) meeh+kabed (emotional pain): my bowels are troubled, my liver is poured upon the earth (Lam. 2:11);

7) nephesh+meeh ('soul, being'): they shall not satisfy their souls, neither fill their bowels (Eze. 7:19);

8) meeh + leeb (emotions, 'heart') : my bowels are troubled; mine heart is turned within me (Lam. 1:20).

\subsubsection{Contrastive analysis of English, French and Serbian translations of meeh}

Gen. 15:4, the first occurrence of meeh, refers to fatherhood, thus eliminating the literal meaning 'womb' and corresponding to halats 'loins', like in Gen. 35:11. While the KJV and the DRB use a calque, modified by the DBY, the NASB and the NKJV (out of thy body, synecdoche), the NIV opts for an equivalent, your own flesh and blood. If Gen. 25:23 is rendered literally by all 15 versions, this shows its literal meaning, without figuration. Still, Ruth's Are there yet any more sons in my womb? (1:11), without being idiomatic, is a rethoric question and as such translated with Am I going to have any more sons? in the NIV, while other versions, although modifying the syntax of the question, keep womb. All five French version keep the image with sein, ventre and entrailles. Of the Serbian/Croatian versions, only the SSP wipes away utroba, with Zar ću roditi još sinova. The expression come forth (out) of one's bowels is found not only in Gen. 15:4, but also, with syntactic variations, in 2 Sam. 7:12, 16:11 and 2 Chr. 32:21 (fatherhood), as well as in Gen. 25:23 (motherhood). Here, as well, the KJV, the DRB and the DBY mostly keep the source image with womb and bowels, whereas the NIV, the NASB and the NKJV mostly replace the phrasemes with equivalents: your/ my/his own flesh and blood (NIV), come out from me, come forth from you, some of his own children (NASB), come from my own/ your body, some of his own offspring (NKJV). In French, the LSG and the OST (sorti de tes/mes/ses entrailles), as well as the CHU (sorti/ra de tes/mes boyaux/viscères) remain faithful to the original, while the TOB (issu de toi-même/ de moi, ses propres fils) 
and the NFC (tes/ses propres enfants/fils) aim at metonymy and equivalence. In Serbian/Croatian 2 Sam. 7:12, all four versions have preserved a body image component, but only the DAN has retained utroba, while the ZBS has od tvoga tijela, the BAK koji će $i z$ tebe izići (synecdoche) and the SSP the excellent od tvoje krvi. For 2 Sam. 16:11, we must note iz/od bedara mojih in the DAN and the BAK (also in 2 Chr. 32:21).

Only two occurrences are found in Job, of which 30:27 seems to suggest that the identity of Hebrew body idioms is primarily semantic, and not morphosyntactic. Namely, My bowels boiled (KJV) expresses the same idea of heat (verb rawtach) in the bowels as do phrasemes with rachamim (Gen. 43:30, 1 Kings 3:26) combined with the verb kawmar. ${ }^{19}$ It is interesting to see how many versions of Job 30:27 modify the source idiom in different ways: I am seething within (NASB, synecdoche), the churning inside me never stops (NIV), My heart is in turmoil (NKJV). In the $\mathrm{DRB}$, my inner parts have boiled seems so deprived of any kind of loftiness. In French, all versions have kept the image component with mes entrailles/viscères bouillonnent/ne cessent de fermenter.

The translation of Psa. 22:14 and 40:8 is interesting because of their Messianic reference. The first places the heart (leeb) in the bowels (meeh), reminding us of the Serbian srce mi je sišlo u pete ('my heart has sunken to my heels'). While the DRB and the DBY keep in the midst of my bowels with the KJV, the three other have within me. In French, while the first four have dans/au fond de mes entrailles/vicères, the modern NFC has Mon courage fond en moi comme la cire. In Serbian/Croatian, the ZBS reads u grudima mojim 'in my breast', while the three other opt for the synecdoche $u$ meni 'in me'. In Psa. 40:8, all six English and all four Serbian/ Croatian versions render meeh with heart/ srce. In French, the OST and the CHU are the only ones to calque the original idiom, while the LSG and the NFC have au fond de mon coeur, and the TOB, of fond de moi.

The beautiful image of the lover's 'growling meeh' in Song 5:4 is rendered variously in English versions: while bowels are kept in the KJV, the DRB and the DBY, only the NASB has a plain translation (my feelings were aroused), and the NIV (my heart

See the final section on Hosea 11:8. 
began to pound) and the NKJV (my heart yearned) replace bowels with heart. All French versions keep the body metaphor, but the NFC has coeur instead of entrailles/ventre/boyaux of the others. The Serbian/Croatian translations use three solutions: a calque in the ZBS and - surprisingly - the SSP, an equivalent body metaphor in the BAK (srce mi ustrepta) and a synecdoche in the DAN (što je u meni ustrepta).

The occurrences of meeh in the Prophets correspond mostly to phrasemes of the type HEART. In them, God or the prophet ache after the consequences of sin in Israel/Juda. Thus in Isa. 16:11 ( $m y$ bowels shall sound like an harp for Moab, KJV) and Jer. 4:19 (My bowels, my bowels! I am pained at my very heart, KJV), meeh is the seat of pain because of the pending disaster. In Isa. 16:11, the DRB and the DBY follow the KJV, while the NIV has my heart laments, the NASB my heart intones like a harp and the NKJV my heart shall resound. In French, the LSG, the TOB and the CHU opt for the calque with mes entrailles frémissent/gémissent, whereas the OST has ma poitrine ('breast, heart') soupire and the NFC reads mon chants sélève avec émotion. Serbian/Croatian versions read as follows: utroba moja [...] dršće (ZBS), utroba moja ječi (DAN), pluća ('breast, chest') moja [...] ječe (BAK), srce mi [...] ječi (NFC).

The specific use of meeh in Jer. 4:19 consists of the repetition - as a syntactic mark of intensification - of my bowels, without any verb or adjective. I am pained at my very heart following this repetition offers the key to its meaning. Still, as such, my bowels, my bowels, identical in the DBY and the DRB, has various alternatives: in the NIV, Oh, my anguish, my anguish!; in the NASB, My soul, my soul!; in the NKJV, O my soul, my soul!

The common feature of the rest of occurrences of meeh in the Prophets, with the exception of the very literal 'belly' in Jonah 1:17 and 2:1, are parallelisms, of which those in Ezekiel will not be commented as having the literal meaning 'belly'. For the rest, two refer to the type BIRTH and the rest to the type HEART. Concerning the first two, Isa. 48:19 (zera+meeh) uses calque in most translations: the offspring of thy bowels (KJV, DRB, DBY) vs. your children (NIV) and your offspring (NASB); les fruits/rejetons de tes entrailles (LSG, OST, CHU) vs. tes descendants (NFC); 
poroda utrobe tvoje (ZBS, DAN, gen. pl. utroba in BAK) vs. tvoje dece (SSP). As Isa. 49:1 joins beten and meeh, it is commented in the section on beten.

The type HEART is represented by Jer. 31:20 (meeh+racham), Lam. 1:20 (meeh+leeb) and Lam. 2:11 (meeh+kabed). In Jer. 31:20, ${ }^{20}$ God expresses his love and compassion for the Northern kingdom of Ephraim by repeating the verb racham: Is Ephraim my dear son? is he a pleasant child? for since I spake against him, I do earnestly remember him still: therefore my bowels are troubled for him; I will surely have mercy upon him, saith the Lord. In the NIV, the NASB and the NKJV, bowels are replaced by heart. In French, the LSG and the OST have mes entrailles sont émues/ se bouleversent. The TOB transforms the parallelism into En mon coeur, quel émoi pour lui. All Serbian/Croatian versions have srce 'heart' (srce mi dršće/ srce je moje ustreptalo).

In Lamentations, Jeremiah observes the destruction of Jerusalem. In 1:20 (KJV, DRB, DBY), meeh is parallel with heart, and preceeded with I am in distress: Behold, o Lord; for I am in distress: my bowels are troubled; mine heart is turned within me... In other English version, we find I am in torment within (NIV) and My spirit/soul is (greatly) troubled (NKJV, NASB).

In 2:11 (KJV), meeh is parallel with kabed 'liver', expressing anguish and pain: Mine eyes do fail with tears, my bowels are troubled, my liver is poured upon the earth, for the destruction of the daughter of my people. My bowels are troubled is repeated in the DRB and the DBY, whereas in the NIV meeh and kabed are replaced: I am in torment within; my heart is poured out on the ground. In the NASB we read My spirit is greatly troubled; My heart is poured out on the earth, and in the NKJV, My heart is troubled; My bile is poured on the ground. In French, the LSG and the OST retain the original image with mes entrailles bouillonnent, the TOB has mon ventre en est remué, while the CHU offers a stronger image with mes boyaux sont en effervescence. The image of the internal organ as a seat of emotion dissapears in the NFC with l'émotion me brûle. In Serbian, all four versions, just as in 1:20, have utroba (utrobe in the BAK), each time with a different

20 We will return to this text in the last section, comparing it to Hos. 11:8 in the DAN. 
verb: utroba moja ustreptala (ZBS)/ se uskolebala (DAN)/ gore mi (BAK)/ ključa (SSP).

\subsection{Racham/rechem: meaning, parallelisms and translations}

\subsubsection{Meaning and parallelisms of $\mathrm{racham} / \mathrm{rechem}$}

Of all the 44 occurrences of racham (פחר), 39 are plurals rachamim refering to the compassion of God, and only 4 correspond to the literal meaning 'womb'. Another interesting cultural feature is revealed by the last occurrence, in Judges 5:30, where racham, 'womb', is a synecdoche for a captive young woman. While rachamim has developed the metaphorical meaning 'compassion', rechem, of the same origin, retains its literal meaning (100\% 'womb'). This is important to keep in mind as some English, French and Serbian translations of rachamim use inhabitual plural forms as well, which is most probably a case of grammatical calque (keeping the source language grammatical category while it is not used in the target language). While the standard plurals in older translations are bowels and French entrailles, mercies is far more frequent in the KJV, the NKJV, the $\mathrm{DRB}$ and the DBY than mercy, and the form compassions appears in the KJV, the NKJV, the DBY, the NIV and the NASB. We even find commiserations in the DRB. In French, besides Chouraqui's systematic calque matrices (lit. 'wombs'), we find compassions in the LSG, the OST and the TOB, as well as miséricordes in the OST and the TOB. In French, Chouraqui translates Neh. 1:11 as donne-les en matrices 'make them find mercy'. Chouraqui systematically invents lexical and syntactic calques in order to reproduce the rhythm and the imagery of the Hebrew original, like the verb matricier (from matrice, 'matrix') for the verb racham. In Serbian, the BAK translates the Plurale Tantum meeh 7 times with utrobe, plural of utroba, 'bowels'.

As of the phrasemes with racham, we consider as such

- phrasemes of the type HEART: tender mercies and manifold mercies (Neh. 9:27; Psa. 25:6; 40:11; 51:1, Psa. 69:16, etc. 
in KJV, NKJV, DRB, DBY); his mercies are great (1 Chr. 21:13; KJV, NKJV, DRB, DBY, NASB) or contracted Great are thy tender mercies in Psa. 119:156; show/grant mercy/compassion to sb (Jer. 42:12; parallelism Dan. 1:9; Zec. 1:9 in KJV, DBY, NIV, NASB, NKJV); her/his bowels yearned upon sb (Gen. 43:30; 1 Kings 3:26); the sounding of one's [...] mercies (parallelism with meeh in Isa. 63:15);

- phrasemes of the type BIRTH: all that openeth the womb (Eze. 20:26); from the bowels/womb (Isa. 46:3).

As we said, rechem always corresponds to the type BIRTH, and forms the following figurative idioms: open/close the womb/ matrix (12/26 occurrences, esp. in the Pentateuch, eg. Gen. 20:18; 29:31; 1 Sam 1:5); (all) that opens the womb/matrix 'firstborns' (e.g. Ex. 13:2.12; Num. 8:16) from the womb 'since birth' (Job 3:11; Psa. 22:10, less than with beten).

Racham occurs in the following 15 parallelisms:

1) noun racham + verb racham: (Deu. 13:17; 1 Kings 8:50; Jer. 42:12)

2) rachamim + hesed: (Psa. 25:6; Isa. 63:7); hesed + rachamim (Psa. 51:1; Psa. 69:16; Psa. 103:4; Jer. 16:5; Lam. 3:22; Dan. 1:9; Hos. 2:19; Zac. 7:9)

3) beten + racham: Isa. 46:3 (from the belly... from the womb, KJV)

4) meeh + racham: Isa. 63:15 (the sounding of thy bowels and of thy mercies, KJV)

Parallelisms with hesed represent $2 / 3$ of all 15 . This suggests the semantic affinity between the two lexemes.

\subsubsection{Contrastive analysis of English, French and Serbian translations of beten}

Given the rather sharp dichotomy separating the meanings of racham and rachamim, as well as the importance od plural forms in the translation of the latter form, this section is structured in a different way. We shall start with the review of lexemes in each English version, and then we shall contrast the translations of some English, French and Serbian texts. For each language, it will be obvious that some versions tend to keep calques, 
while others prefer equivalence. After that, we will offer some conclusions.

- KJV: 26 mercies (11 tender mercies and 2 manifold mercies); 4 mercy; 5 compassion (2 compassions); 2 bowels (his bowels did yearn upon his brother in Ge. 43:30, her bowels yearned in 1. Kings 3:26); 4 womb (including open the womb and from the womb). The prevalence of plural forms - bowels, mercies, compassions - is remarkable, as in the DRB.

- DRB: 19 mercies (shut up his mercies in Psa. 77:9; 7 tender mercies; 6 many mercies; in Zech. 1:16 I will return to [...] in mercies; in Psa. 106:46 he gave them unto mercies for 'he provoked pity for them'); 7 mercy; 3 bowels (her bowels were moved in 1 Kings 3:26, bowels of compassion rendering a parallelism with hesed in Psa. 25:6, or in bowels of the wicked in Pro. 12:10); 3 compassion; 4 womb (Isa. 46:3 replaces from the womb by by my womb); heart (his heart was moved, Gen. 43:30); favorable ( transposition $\mathrm{N} \rightarrow$ Adj, Gen. 43:14); 3 commiserations (Hos. 2:19 and Lam. 3:22 with hesed); pity; kindness (preceding hesed in parallelism).

- DBY: 26 mercies (12 tender mercies; 4 manifold mercies); 6 compassion (in Lam. 3:22 compassions); 5 mercy; 4 womb (Isa. 46:3 from the womb); 2 bowels (Ge. 43:30 his bowels burned for his brother; 1 Kings 3:26 her bowels yearned over her son).

- NIV: 17 compassion (1 compassions in Lam. 3:22); 14 mercy (replacing mercies in KJV, DBY, DRB); 2 womb (including Gen. 49:25); favor; pity; merciful (transposition $\mathrm{N} \rightarrow$ Adj.); deeply moved (Gen. 43:30 and 1 Kings 3:26, transposition $\mathrm{N} \rightarrow$ Adj). The dynamic equivalents for rachamim in this translation are: unfailing love (Psa. 51:1); the kindest acts (Pro. 12:10); since you were born (Isa. 46:3; for from the womb). Finally, rachamim of Amos 1:11 seems to be omitted.

- NASB: 30 compassion (compassions for Lam. 3:22); 5 mercies (His mercies are many/great) and 2 mercy; 3 womb (from the womb in Isa. 46:3); 2 dynamic equivalents (2 he/she was deeply stirred over $s b$ in Gen. 43:30 and 1. Kings 3:26).

- NKJV: 21 mercies (7 great/abundant/manifold mercies, 12 tender mercies); 9 mercy; 5 compassion (compassions in Lam. 3:22); 3 womb (like KJV); 2 pity (1 noun, 1 verb); 1 goodwill (Dan. 1:9). As for yearning bowels, Gen. 43:30 and 1. Kings 3:26 have 
kept yearn, but rahamim is replaced by heart in Gen. 43:30 and by compassion in 1 Kings 3:26, thus removing bowels entirely for rahamim. Nevertheless, the idiom in Isa. 63:15 is kept, together with the parallelism: the sounding of thy bowels (meeh) and of thy mercies (rahamim).

The frequent translation of rachamim by adding tender to mercies represents an example of explicitation, which makes "explicit in the target language what remains implicit in the source language" (Vinay \& Darbelnet, 1972:9; 1995:342)..

The translation of parallelisms, esp. with hesed, affects the choice of a lexical equivalent for rachamim. Namely, each version, whether in English or in the other two languages, has a primary, prototype lexeme for racham(im), which can vary in parallelisms, when the standard word is combined with a synonym. For example, if the KJV uses typically mercies, it will combine it with compassion (e.g. Lam. 3:22), whereas the DRB will translate rachamim exceptionally as commiserations in Jer. 16:5 in the parallelism with mercy (hesed + rachamim).

Of all the translations, the DBY is, as expected, the most prone to literal translation and syntactical calque. It has the same number of mercies and womb as the KJV, with more tender mercies and manifold mercies, and a similar number of compassion and bowels. The NIV, on the contrary, often uses different oblique translations procedures, like transposition in deeply moved in Gen. 43:30 and 1 Kings 3:26, and amplification in unfailing love of Psa. 51:1 and kindest acts of Pro. 12:10. The parallelism from the belly... from the womb of the KJV Isa. 46:3 is rendered by a double equivalence as since your birth... since you were born. As for the sounding of thy bowels and of thy mercies (Isa. 63:15), the NIV, as well as, surprisingly, the DRB, replace them with abstract words tenderness and compassion (plain words or mots signes, opposed to mots images, i.e. figurative words, Vinay \& Darbelnet 1972:11). The DBY opts for a half-way Your heart and Your compassion. Finally, firstborn of Eze. 20:26 in the NIV, the NASB and the NKJV represents both equivalence and concentration, in terms of Vinay \& Darbelnet (1972:7).

As for the French versions, we observe a series of lexemes for rachamim in all versions except the CHU, where it is translated by matrices. Nouns compassion(s), miséricorde(s) and bonté 
are often accompanied by grande(s). The verb trouver is frequent with compassion(s), miséricorde(s).

The idiom of Gen. 43:30 is rendered with ses entrailles étaient émues (LSG, OST), ému jusqu'aux entrailles (TOB). The CHU uses a deliberately archaic calque ses matrices ardaient, while the NFC completely obliterates the image component with était si ému. We find similar translations in 1 Kings 3:26 of the LSG, the OST and the TOB. The CHU has once again ses matrices ardaient, and the NFC the plain poussée par son profond amour.

The parallelism beten +racham in Isa 46:3 keeps both phrasemes only in the TOB and the $\mathrm{CHU}$, while the three other replace at least racham with an equivalent (dès votre naissance in the OST, avant que vous ayez vu le jour in the NFC, and des votre origine... dès votre naissance of the LSG).

Isa. 63:15, with its parallelism meeh +racham, renders meeh mostly by keeping the figurative expression, while using a plain noun for rachamim: le frémissement/lémotion de tes entrailles et tes compassions (LSG, OST) and l'émoi de tes entrailles et tes tendresses (TOB). The CHU uses l'émotion de tes entrailles, de tes matrices (CHU) and the NFC, two plain nouns tes sentiments de tendresse $[. .$.$] ton affection.$

For Eze 20:26, all versions but the CHU have tous leurs premiers-nés, while the $\mathrm{CHU}$ has the literal tout fendeur de matrice.

In Serbian/Croatian, we observe the presence of the following lexemes and phrasemes:

- DAN: 20 milost 'mercy'; 8 milosrde 'compassion'; 3 materica 'womb'; 2 srce 'heart' (goraše mu srce od ljubavi 'heart burned of love', Gen. 43:30); 2 žalostiv 'compassionate' (transposition, Zec. 7:9); 2 žaljenje 'pity' (Jer. 16:5); dobrota 'goodness'; 1 ljubav 'love' (Dan. 1:9); utroba 'womb, bowels' (uskoleba se utroba '(her) womb was stirred', 1 Kings 3:26); rođenje 'birth' (Isa. 46:3); two transpositions into verbs umilostiviti 'arouse pity' (1 Kings 8:50) and žaliti (Psa. 106:46).

- BAK: 15 milosrde 'compassion'); 12 milost 'mercy'; 2 srce 'heart' (1 s. mu uzdrhta pred bratom 'his heart trembled in front of his brother', equivalence); 2 utroba 'womb, bowels' (ustrepta $z a$ sinom 'stirred for her son', calque); naklonost 'favour'; samilost 'compassion'; dobrota 'goodness'; provorođeno 'firstborn' ( Eze. 
20:26); rođenje 'birth' (od rođenja vašeg, 'since you were born', Isa. 46:3, metonymy); ljubav 'love'; žaljenje 'pity'. As for transpositions, there are umilostiviti 'arouse pity' (1 Kings 8:50), žaliti 'pity', milosrdan 'compassionate', žalostiv 'compassionate'.

- ZBS: 12 milosrde 'compassion'; 7 smilovanje (1 plural smilovanja 'mercies, compassions'; a rare syntactic calque in Psa. 77:9 ili je gnjevan zatvorio smilovanje svoje 'or has He closed his pity in His anger'); 5 milost 'mercy'; 4 samilost 'compassion'; 3 srce 'heart', Pro. 12:10); 2 ljubav 'love'; 2 dobrota 'goodness'; 2 utroba 'womb, bowels', (literal in Gen. 49:25; metaphor in Prov. 30:16); nježnost 'tenderness'; sućut 'compassion, pity, condolences'; krilo 'bosom' (Isa. 46:3); prvorođenčad 'firstborns'; 2 transpositions milosrdan 'merciful'.

- SSP: 25 samilost 'pity'; 2 milost; utroba; materica; srce; sažaljenje; prvorođenčad. We find 5 transpositions smilovati se 'show mercy', as well as sažaliti se, milostiv, samilostan, blagonaklon. Two equivalences are silno uzbuden što vidi brata (for his bowels did yearn upon his brother in Ge. 43:30 of the KJV) and od kada ste se rodili (from the womb in Isa. 46:3 of the KJV, racham).

As we can see, in the DAN, the BAK, the ZBS and the DAN, and, to a lesser extent in the SSP, several nouns, adjectives and verbs contain the same lexical roots -mil- ('dear': milost, milosrde, smilovanje, samilost, umilostiviti, milosrdan) and -žal- ('pity, sorrow’: žaliti, (sa)žaljenje, žalostiv). They all represent non-figurative, or plain equivalents for racham.

As illustrated by numerous examples so far, none of the phrasemes studied is an entirely invariable petrified structure. Fernando (1996:43; in van den Heever 2013:50,51) recognizes four major types of transformations idioms can(not) undergo: replacements (or substitutions, in number, tense, etc.), additions (e.g. such as my brother's dog's keeper, in Crystal 2011:37:47), deletions (dangle a carrot before the donkey vs. Thatcher waves trade carrot, 1996:51; in van den Heever 52) and permutations (a brick dropper vs. to drop a brick). These four types are very similar to certain types of translation procedures mentioned by Vinay and Darbelnet (1972:4 et sqq) and present in our corpus. 


\section{Bible idioms, adaptation and acculturation}

Finally, we shall consider the interesting case of adoption of an OT idiom in the DAN translation (Serbian) of Hosea 11:8, although such an idiom is not found in the Hebrew original. As Taber and Nida pointed out, there are three types of "semantic adjustments" in translation: "a) from idioms to nonidioms; b) from idioms to idioms; c) from nonidioms to idioms" (1982:106), and the DAN translation of Hos. 11:8 is a rare example of the type c. In other words, it is not a calque, but an adoption of a Hebrew structure in the translation:

- YLT: [...] Turned in Me is My heart, kindled together have been $M y$ repentings [Heb. nichum].

- DAN: [...] Ustreptalo je srce moje u meni, uskolebala se utroba moja od žalosti ['my bowels have been stirred in sorrow'].

- KJV: [...] mine heart is turned within me, my repentings are kindled together.

In the last third of this verse, where even $\mathrm{CHU}$ reads Mon coeur [Heb. leeb] se retourne sur moi, et mes réconforts [Heb. nichum, בוּחנ 'compassion'; Fr. 'confort'] ensemble se réchauffent, Daničić translates the whole clause contaning nichum with a calque corresponding to rachamim, although the source text does not contain BMR. While Serbian disposes of several idioms with srce ('heart'), Daničić chose a Hebraism. Why, and with what result?

The immediate context of nichum in Hos. 11:8 is the verb kamar (רבמְכ) 'heat, become hot, stir, kindle', translated as kindled in the YLT and the KJV. On the paradigmatic level, this verb points to other two of its four occurrences - in Gen. 43:30 and 1 Kings 3:26 - where it forms with rachamim the idiom one's bowels yearn/are stirred, referring to Joseph's love for his brother Benjamin and to a mother's love for her newborn. In his commentary of Hos. 11:8, ${ }^{21}$ Rashi mentions the last of four occurrences of true $>26.4 .2020$. 
kamar, Lam. 5:10 (Our skin is hot [kamar] as an oven, because of the fever of famine). Considering the DAN translation of Hos. 11:8, we argue that kamar of Hos. 11:8 might have been contextually contaminated (Galatanu 2016, her French term is contamination contextuelle) by rachamim in Gen. 43:30, 1 Kings 3:26, so as to associate kamar with rachamim even in the absence of the latter - in Hos. 11:8. Or rather, could that have been the contextual contamination not in Hebrew, but in the Serbian text of the DAN itself, since the same phrase utroba se moja uskoleba is found in Hab. 3:16: "Čuh, i utroba [beten] se moja uskoleba [...]" Interestingly enough, utroba stands here for beten; in this way, Daničić (and three other) translates beten and rachamim by the same word, utroba. In other words, identical Serbian translations confirm the semantic affinity of beten and rachamim, because they appear in the same Serbian translation utroba se uskolebala. Furthermore, the ZBS has also translated Hos. 11:8 by activating the same image: "Srce mi je uznemireno, uzavrela mi sva utroba [...]" Nonetheless, the DAN adds od žalosti ('of sorrow'), which is an example of explicitation; in other words, the DAN adds the literal meaning to the idiom.

From a wider contextual point of view, the adoption of the calque from Gen. 43:30 and 1 Kings 3:26 is also motivated by the very subject of this section of Hosea, which can be resumed by Hos. 13:9: "O Israel, thou hast destroyed thyself; but in me is thine help." The same theme and similar vocabulary as in Hos. 11:8 is found in Jer. 31:20 (which also contains a triple parallelism):

Is Ephraim my dear son? is he a pleasant child? for since I spake against him, I do earnestly remember him still: therefore my bowels [meeh] are troubled for him; I will surely have mercy upon him, saith the LORD.

Once again, the parallelism of meeh and rachamim expresses the painful love of a father. To conclude, in the context of Hos. 11 , where God is torn between pity and justice, Daničić has activated an idiom whose expressive power resides in the image component associating the organ/seat of reproduction with parental love. Therefore, the idiom is far more than just a figurative way of 
expressing compassion. For an English or French reader, a Latin equivalent for BMR can best activate this same image component when we speak of a visceral love. The idiom translation of Hos. 11:8 in the DAN (cf. my compassion is aroused, NIV) intensifies the general message of Hosea. Without such idioms, any translation of the Bible would be, in Krunoslav Pranjićs wording, "an esthetically worthless alternative of mere informativity" (Cro. "estetički nulta inačica puke izvještajnosti”, 1986). Finally, this example of adoption also reveals the multidimensionality of Bible idioms and the importance of their preservation, if possible, in the translation : not only because of their esthetic and emphatic function, but also because of all the cross-textual associations and messages their imagery evokes in the mind of the reader.

\section{Conclusions}

The root meaning 'womb, bowels' of beten, meeh and $\operatorname{racham}(\mathrm{im})$ is present in their literal and figurative uses. Each lexeme forms several phrasemes of two semantic types, BIRTH and HEART. Phrasemes of the type BIRTH are based on metonymy, while those of the type HEART are based on the body metaphor representing womb or bowels as the seat of deep love and attachment to a child/kin. On the whole, the phrasemes with BMR show the following types of variations:

1. The noun head of some phrasemes can vary, in Hebrew and in translations. The most important case is that of from the/one's womb/bowels, where English bowels/womb corresponds to all three lexemes BMR. The idiom come forth/proceed from one's bowels corresponds to $B$ and $M$. In spite of this alternation of the head noun, it is difficult to deny the identical global meaning of the idiom.

2. Another important variation is the replacement, or the switching between a noun and the corresponding verb in a phraseme, like in the case of racham, noun and verb. Also, Isa. 63:15 has the noun hamon for the SOUNDING of thy bowels and of thy mercies, while Songs 5:4 has the verb hamah for my bowels were MOVED for him. Having the same root, they form the same phraseme. 
3. Besides the variation of the main lexeme, phrasemes of the type BIRTH show less morphosyntactic variations than the type HEART. Such morphosyntactic variation in a phraseme suggests once more that its identity is semantic rather than structural. For example, phrasemes with meeh include: my bowels were moved for him (Song 5:4, KJV), the multitude of Thy bowels and Thy mercies (Isa. 63:15), My bowels, my bowels! (Jer. 4:19). Our hypothesis is that, for the type HEART, figuration already concerns the noun head, with its metaphoric meaning, so that its phraseological value depends less on a fixed structure. This is especially visible for racham, whose metaphoric meaning, moreover, is morphologically marked by the opposition Singular-Plural. As WarrenRothlin puts it, "there may in fact be a lot of stylistic and syntactic flexibility in the form of an idiom." (2005:206)

As for the type BIRTH, where the lexemes have their literal meaning, phraseological value of restricted collocations (for the most part) corresponds to a greater morphosyntactic fixedness.

4. Both types of phrasemes appear in numerous parallelisms, where all three lexemes can combine with each other and several others. This shows not only the range of semantic hues for each of the lexemes, but also important semantic overlappings.

Finally, as concerns the fifteen translations examined, each of them shows greater or lesser affinity for literal or oblique translation procedures, thus representing a continuum. All translations taken into consideration, we could represent this continuum as follows, for each language:

Literal translation $\rightarrow \rightarrow \rightarrow \rightarrow \rightarrow \rightarrow \rightarrow \rightarrow \rightarrow \rightarrow \rightarrow \rightarrow \rightarrow$ Equivalence

English $\quad \mathrm{DBY} \rightarrow \mathrm{DRB} \rightarrow \mathrm{KJV} \rightarrow \mathrm{NKJV} \rightarrow \mathrm{NASB} \rightarrow \mathrm{NIV}$

$\begin{array}{llll}\text { French } & \mathrm{CHU} \rightarrow \quad \mathrm{OST} \rightarrow \mathrm{LSG} \rightarrow \quad \mathrm{TOB} \rightarrow \quad \mathrm{NFC}\end{array}$

Serbian/Cro. $\mathrm{DAN} \rightarrow \mathrm{ZBS} \rightarrow \mathrm{BAK} \rightarrow \mathrm{SSP}$

In other words, older English versions like the KJV, the DRB and the DBY, as well as the CHU, more than any other version, are the most faithful to the Hebrew phraseology. On the other end of the continuum, modern translations NIV, NFC and SSP, display the greatest number of equivalences and plain translations, which erase the image component of many phrasemes. 
Such solutions deliberately abandon even the well-known, semiproverbial expressions in order to secure the comprehensibility of an elementary message. Between these poles, all other versions combine literal translation and equivalence, using various oblique translation techniques (modulation, transposition, equivalence, adaptation, condensation).

\section{Bibliography}

Bouttier, Michel. "Traductions récentes du Nouveau Testament". Études théologiques et religieuses 47.3 (1972): 369-374. Web. 20.05.2020.

Cary, Edmond. Comment faut-il traduire? Lille: Presses Universitaires de Lille, 1985. Web 02.04.2020.

Crystal, David. The Influence of the King James Bible on the English Language. Conference organised by the English Speaking Union, British Council, July 6 2011. Web 12.08.2018.

Colson, Jean-Pierre. „Cross-linguistic phraseological studies: An overview". Sylviane Granger \& Fanny Meunier (eds). Phraseology: an interdisciplinary perspective. Amsterdam/ Philadelphia: John Benjamins, 2008. 191-206.

Coats, George W. „Self-Abasement and Insult Formulas”. Journal of Biblical Literature 89.1 (1970): 14-26. Web. 15.02.2020.

Cowie, Antony Paul. "The treatment of collocations and idioms in learners' dictionaries." Applied Linguistics 2.3 (1981): 223-235.

Dąbrowska, Anna. A Syntactic Study of Idioms. Psychological States in English and Their Constraints, Newcastle upon Thyne: Cambridge Scholars Publishing, 2018.

Dagut, Menachem. A Linguistic Analysis of Some Semantic Problems of Hebrew-English Translation, Ph. D. thesis. Hebrew University of Jerusalem, 1971.

Delisle, Jean. La traduction raisonnée. Manuel d'initiation à la traduction professionnelle de langlais vers le français. Ottawa: Presses de l'Université d'Ottawa, 1993.

Dobrovol'skij, Dmitrij. „Idiom dictionaries”. Keith Brown (ed). Encyclopaedia of Language and Linguistics, 2 nd edition. Amsterdam et al.: Elsevier, 2006. 514-517.

Dobrovol'skij, Dmitrij Olegovitch. \& Elisabeth Piirainen. Figurative language: Cross-cultural and cross-linguistic perspectives. Amsterdam et al.: Elsevier, 2005. 
Dobrovol'skij, Dmitrij Olegovitch \& Elisabeth Piirainen. „Idioms: Motivation and etymology". Yearbook of Phraseology 1 (2010) 1: 73-96. Web. 30.01.2020.

Galatanu, Olga. « La bivalence axiologique de 'l'autorité” et de ses discours. Le cas des discours dans l'espace universitaire ", Corela [online], HS-19 | 2016, published June 8 2016. Web. 19.05.2020.

Gläser, Rosemarie. „The stylistic potential of phraseological units in the light of genre analysis". Anthony Paul Cowie (ed.). Phraseology: Theory, Analysis, and Applications, Oxford: Clarendon Press, 1998. 125-143.

Granger, Sylviane, Magali Paquot. "Disentangling the phraseological web”. Sylviane Granger \& Fanny Meunier (eds). Phraseology: an interdisciplinary perspective. John Benjamins, 2008. 27-50.

Fauconnier, Gilles and Mark Turner. The Way We Think: Conceptual Blending and The Mind's HIdden Complexities. New York: Basic Books, 2002.

Heever, Cornelius Marthinus van den. Idioms in Biblical Hebrew. Towards their identification and classification with special reference to 1 and 2 Samuel, Ph. D. dissertation. Stellenbosch University, 2013. Web. 20.10.2019.

Loewen, Jacob A. "Non-literal Meanings III. Practical suggestions for translators". TBT. 27.2 (1976): 201-207. Web 15.04.2020.

Margot, Jean-Claude. Traduire sans trahir. La théorie de la traduction et son application aux textes bibliques. Lausanne: L'Âge d'Homme, 1979. Printed.

Omazić, Marija. „Processing of idioms and idiom modifications”. Sylviane Granger, Fanny Meunier (eds). Phraseology: an interdisciplinary perspective. Amsterdam/Philadelphia: John Benjamins, 2008. 67-80. Printed.

Pranjić, Krunoslav. "Daničićev Stari zavjet”. Jezikom i stilom kroza književnost. Zagreb: Školska knjiga, 1986. Web. 20.04.2020.

Reiss, Katharina. Möglichkeiten und grenzen der Überzetzungskritik. München: Hueber Verlag, 1971. Printed.

Reiss, Katharina. Translation Criticism - The Potentials and Limitations. Translated by Erroll F. Rhodes. Abingdon: Routledge, 2014. Printed.

Taber, Charles Russell, Eugene Albert Nida. The Theory and Practice of Translation. Leiden: Brill, [1969] 1982. Printed.

Taber, Charles Russell; Eugene Albert Nida. La traduction: théorie et méthode. London: ABU, 1971. Printed.

Turner, Mark. "Conceptual Integration", The Oxford Handbook of Cognitive Linguistics, Oxford: OUP, 2007. 377-393. Printed. 
Venuti, Lawrence. "Strategies of Translation". Mona Baker (ed). Routledge Encyclopedia of Translation Studies. London/New York: Routledge, [1998,] 2001. 240-244. Printed.

Vinay, Jean-Paul, Jean Darbelnet. Stylistique comparée du français et de langlais. Méthode de traduction. Paris: Didier, [1958] 1972. Printed.

Vinay, Jean-Paul, Jean Darbelnet. Comparative Stylistics of French and English. A methology for translation. Translated and edited by Juan C. Sager \& M.-J. Hamel. Amsterdam/Philadelphia: John Benjamins, 1995. Printed.

Vrbinc, Alenka. A Cross-linguistic and Cross-cultural Analysis of English and Slovene Onomastic Phraseological Units. Cambridge Scholars Publishing, 2019. Printed.

Waard, Jan de. "Biblical Metaphors and Their Translation". The Bible Translator 25.1 (1974): 107-116. Web. 30.03.2020.

Warren-Rothlin, Andy L. "Body idioms and the Psalms". Philip S. Johnston and David G. Firth (eds). Interpreting the Psalms: Issues and approaches. Leicester: IVP Apollos, 2005. 195-212. Web. 20.04.2020.

\section{Abbreviations of Bible translations}

BAK Biblija prevod Luje Bakotića, 1933.

ZBS Zagrebačka Biblija "Stvarnost", 1968.

CHU La Bible Chouraqui, 1974-1979.

DAN Daničić Old Testament, 1865.

DBY Darby Bible Translation, 1890.

DRB Douay-Rheims Bible Old Testament, 1609-1610.

GNB Good News Bible, 1976.

KJV King James Bible, 1611.

LSG Bible Louis Segond, 1910.

NASB New American Standard Bible, 1971.

NFC Nouvelle Français Courant, 2019.

NIV New International Version, 1978.

NKJV New King James Bible, 1982.

OST Bible Révision Ostervald, 1724, 1996.

TOB Traduction Oecuménique de la Bible, 1967-1975, 2010.

SSP Savremeni Srpski Prevod, 2016.

VUK Vuk Karadžić New Testament, 1847.

YLT Young Literal Translation, 1862. 


\section{Татјана Самарџија}

\section{ЕНГЛЕСКИ, ФРАНЦУСКИ И СРПСКИ ПРЕВОДИ БИБЛИЈСКИХ ФРАЗЕМА С ИМЕНИЦАМА BETEN, MEEH И RACHAM}

У раду разматрамо старозаветне фраземе с именицама beten, meeh и racham, које деле коренско значење 'материца, утроба'. Ови фраземи, у распону од колокација до фигуративних идиома, припадају двама семантичким типовима: РАЂАЊЕ (йлоg уйробе итд.) и СРЦЕ (уйроба му се усколебала итд). Поредимо петнаест енглеских, француских и српских/ хрватских превода Библије, полазећи од тога да динамички преводи бришу „сликовну компоненту” (Добровољски и Пираинен 2010), којом се остварује емфатичка улога идиома, што за последицу има осиромашен превод. Везу идиома и контекста сагледавамо кроз пример Даничићевог превода Осије 11:8.

Кључне речи: Библија, превођење, фразем, идиом, beten, meeh, rechem, утроба, материца. 